\title{
OBSERVATION OF COASTAL FRONT AND CIRCULATION IN THE NORTHEASTERN JAVA SEA, INDONESIA
}

\author{
Agus S. Atmadipoera ${ }^{1 *}$, Edi Kusmanto ${ }^{2}$, Adi Purwandana ${ }^{2}$, and I Wayan Nurjaya ${ }^{1}$ \\ ${ }^{1}$ Oceanography Division, Department of Marine Science and Technology, Bogor \\ Agricultural University (IPB Bogor), Bogor-Indonesia \\ *E-mail: atmadipoera_itk@ipb.ac.id \\ ${ }^{2}$ Center for Research and Development of Oceanology, Indonesian Institute of \\ Science (P2O-LIPI), Jakarta, Indonesia
}

\begin{abstract}
The structure and spatial extent of a coastal front and circulation in the shallow ( $<55 \mathrm{~m}$ depth) northeastern Java Sea in Indonesia was investigated with a new dataset of high-resolution conductivity-temperature-depth (CTD) and along-track shipboard acoustic Doppler current profiler (SADCP) during a DIKTI-LIPI 2010 joint research cruise on R.V. Baruna Jaya 8. The coastal front separates fresh warm coastal water derived mainly from Barito River discharge and the saline, cool Java Sea water. The surface fresh water plume extends approximately $760 \mathrm{~km}$ from the Barito River estuary to the south, and its thickness varies from the surface to $10 \mathrm{~m}$ and $20 \mathrm{~m}$ depth, depending on its proximity to the fresh water source. The front is aligned a northeast and east direction, probably related to a meandering of strong northeastward monsoon current in the eastern part of the Java Sea during the observation time.
\end{abstract}

Keywords: hydrographic measurement, coastal front, Matasiri Islands, Barito River, the northwest monsoon current

\begin{abstract}
ABSTRAK
Struktur dan jangkauan spasial front pantai serta sirkulasi di Laut Jawa bagian timurlaut yang relatif dangkal (kedalaman $<55 \mathrm{~m}$ ) dikaji dengan dataset baru dari hasil pengukuran temperatureconductivity-depth (CTD) resolusi-tinggi dan shipboard acoustic Doppler current profiler (SADCP) sepanjang lintasan survei dari pelayaran DIKTI-LIPI 2010 dengan Kapal Riset Baruna Jaya 8. Front pantai memisahkan massa air bersalinitas lebih rendah dan hangat yang utamanya berasal dari gelontoran Sungai Barito dengan massa air bersalinitas lebih tinggi dan dingin dari massa air Laut Jawa. Plume air bersalinitas rendah dekat permukaan meluas kearah selatan sampai sekitar $760 \mathrm{~km}$ dari estuari Sungai Barito, dan ketebalannya bervariasi dari 0 sampai 20 m, tergantung pada dekatnya dengan sumber air sungai. Front di kawasan perairan Kepulauan Matasiri terbentuk sejajar dalam arah timurlaut dan timur, diduga terkait dengan meandering arus monsoon Jawa yang mengalir kuat kearah timurlaut pada waktu pengamatan berlangsung.
\end{abstract}

Kata kunci: pengukuran hidrografi, depan pantai, Laut Jawa, Kepulauan Matasiri, Sungai Barito, arus monsoon Jawa

\section{INTRODUCTION}

The northeastern waters around the Matasiri Islands are among the most important fishing ground areas for small pelagic fishes in the Indonesia Java Sea (Potier and Boely, 1990; Pasaribu et al., 2004), where the fish abundance and migration are controlled by local primary productivity due to river discharge and seasonal salinity changes
(Petit et al., 1996). Modeling the studies (Tozuka et al., 2007; Atmadipoera, 2009) the show that and the eastward Java Sea (JS) monsoon current associated with the freshening season, is developed during the northwest monsoon (NWM), in contrary to that in the southeast monsoon (SEM) period, where salty water from Makassar Strait is advected into the JS (Figure 1). The freshening is due to high direct precipitation over the JS 
region, as well as to a large discharge from many big rivers surround the JS. This fresh water significantly impacts the property structure of the Indonesian Throughflow (ITF) water as the ITF water exit the outflow straits into the Indonesian Ocean (Atmadipoera et al., 2009).

The southern Kalimantan Barito River discharge (Figure 1) has been considered to affect the coastal environment around this region such as seasonal salinity distribution, abundance of pelagic fishes, and surface chlorophyll- $a$ distribution (Petit et al., 1996; Sadhatomo and Durand, 1997; Hendiarti et $a l ., 2005)$. In a previous hydrographic observational studies so far little attention has been devoted to investigate structure and spatial extent of coastal front due to Barito river plume in this valuable fishing ground area.
In response to the lack of knowledge because of sparse hydrographic measurement that has not been investigated in previous studies, a multi-disciplinary study was carried out around the Matasiri Islands, South Kalimantan, known as the DIKTI-LIPI Joint Research Cruise, aboard the R.V. Baruna Jaya VIII (BJ8) in November 2010 (Figure $2)$. Results of biogeochemical and fisheries studies have been partly reported elsewhere (Purwangka et al., 2012; Wijaya and Pratiwi, 2011; Munasik and Siringoringo, 2011; Thoha and Amri, 2011). Here, we describe the physical aspects, particularly the structure of the hydrographic properties related to the formation of a coastal front, based on the conductivity temperature depth (CTD) and shipboard acoustic doppler current profiler (SADCP) measurements. The objectives

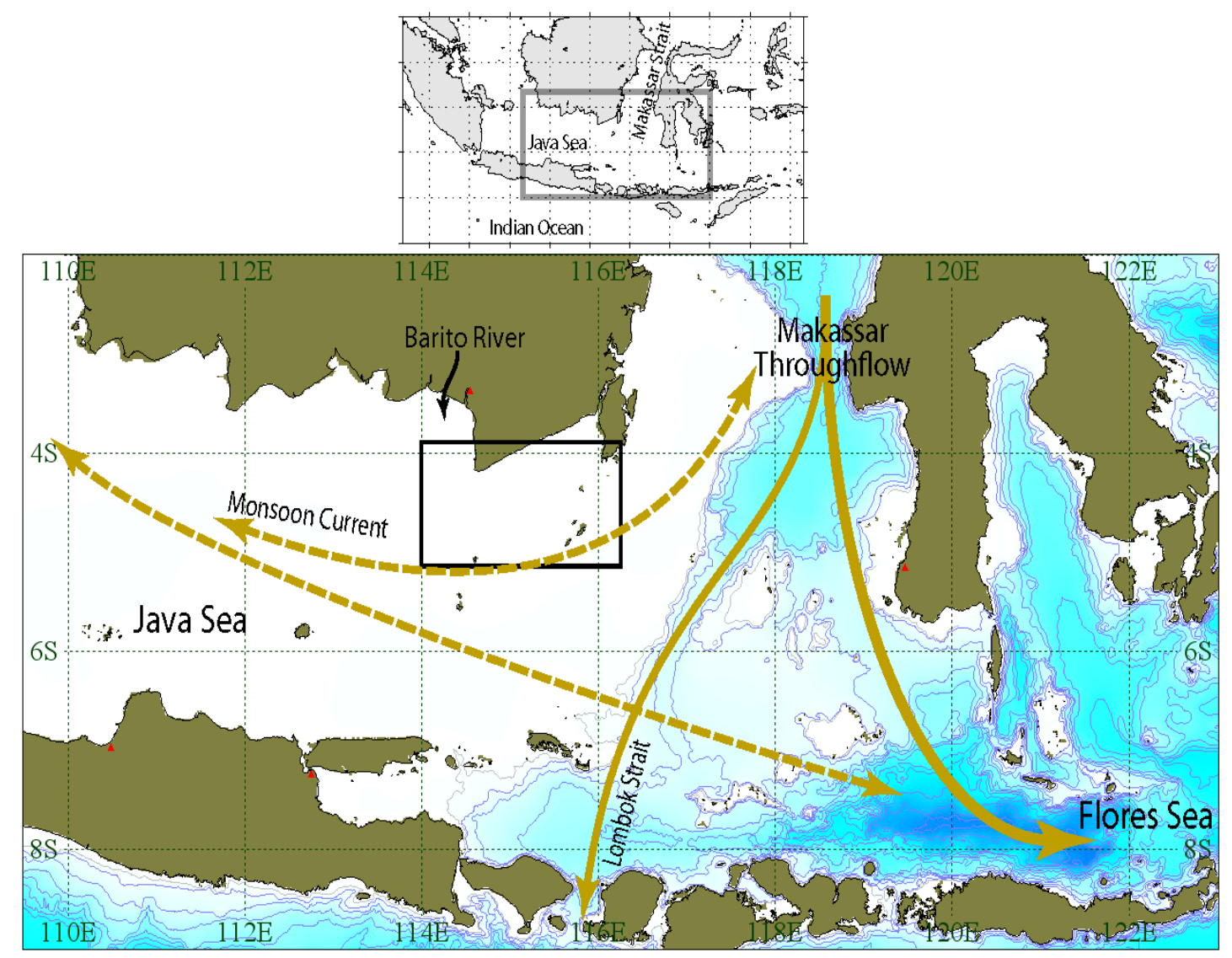

Figure 1. Schematic reversal near-surface monsoonal circulation (dashed arrows) and persistent thermocline Makassar ITF (bold arrows). Black rectangle denotes the study area during the DIKTI-LIPI joint-research cruise in November 2010. 
of this study were to investigate the hydrographic properties and circulation in the study area, and in particular to investigate the structure and spatial extent of coastal fronts around Matasiri Islands and their implication to local water mass distribution. This was the first study to provide observations of the physical processes of coastal fronts in the region.

\section{METHODS}

\subsection{Time and Study Area}

The Joint research DIKTI-LIPI cruise around the Matasiri waters, South Kalimantan, was carried out from 21 to 27 November 2010. The survey transect activity commenced in the western Java Sea and then headed east towards to the area around the Matasiri
Islands (Figure 2). The survey work was briefly interrupted for onshore survey activities around Matasiri islands, such as fish and coral reefs observations, sampling of seaweeds and mollusks, and setting mini beach seines and bottom trawling for the sampling of fishes. The survey then continued with the final transect, extending from the southeastern area to the northwestern stations near the Barito River (Figure 1).

Bathymetry in the study area varies between $15 \mathrm{~m}$ and $55 \mathrm{~m}$ depth. Shallower waters (depth $<25 \mathrm{~m}$ ) are found south of the Kalimantan peninsula, and from the Matasiri Islands to the north. The deepest waters are found in the eastern Matasiri Islands (> $55 \mathrm{~m}$ depth), which indicate the beginning of the continental shelf slope toward the east.

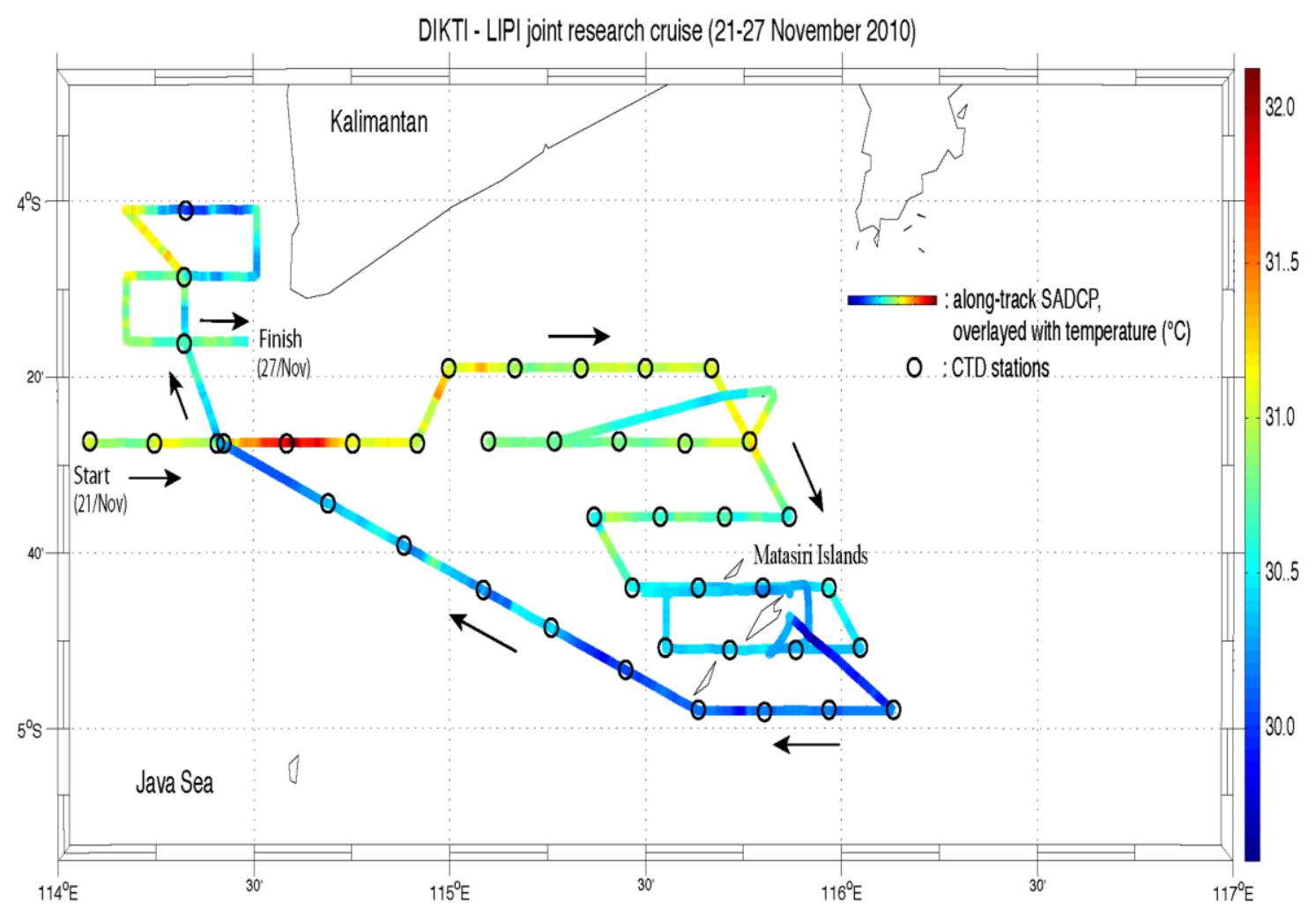

Figure 2. Seawater temperature $\left({ }^{\circ} \mathrm{C}\right)$ along the cruise-track at $8 \mathrm{~m}$ depth from temperature sensor of hull-mounted shipboard acoustic Doppler current profiler (SADCP). Circles denote locations of CTD stations. The survey was commenced from westernmost area on November 21, following arrows, and finished on November 27, 2010, in the southernmost part of Kalimantan. 


\subsection{CTD Data}

A Seabird 911 plus of Conductivity Temperature Depth (CTD) profiler was used to measure salinity, temperature and depth from the surface down to usually about $1 \mathrm{~m}$ above the seabed. Conductivity, temperature, and pressure were sampled at $24 \mathrm{~Hz}$. A total of 41 casts were collected during the cruise. CTD Station measurements (Figure2) stretched from the northwestern area (closer to Barito River) to the southeastern area near Matasiri Islands. The high resolution stations were mainly concentrated around Matasiri Islands. A SBE 43 dissolved oxygen (DO) and Chelsea Aqua 3 fluorescence sensors for chlorophyll-a concentration were also included in the deck unit.

Processing of the CTD data using the standard Sea Bird Electronics methodology included conversion from HEX file format into $\mathrm{CNV}$ format, correcting for temporal and thermal lags, data filtering by a low-pass filter scheme to smooth the high frequency data, and bin averaging by depth (Seasoft V2, 2006). Since the water depth in the study area was relatively shallow $(<55 \mathrm{~m})$ and gradient salinity was very high, the data bin average was conducted at $1 \mathrm{~m}$ vertical resolution.

Spikes or noises that might still emerge from the filtered CTD data were checked manually by looking at each CTD profile. If a spike or noise was found it was removed and the data replaced by linear interpolated data. CTD data files were then reformatted following Ocean Data View (ODV; Schlitzer, 2009) for further processing and analysis of the data, such as to calculate the density gradient of seawater, and the Brunt-Vaisala frequency.

\subsection{Shipboard ADCP Data}

ARDI hull mounted shipboard acoustic Doppler current profiler (SADCP $75 \mathrm{kHz}$ ) was employed to measure current speed and direction along the cruise track. Current profiles measured by SADCP were divided into bins (cells). One bin was equal to a nominal
$5 \mathrm{~m}$ depth. Following RD Instrument (2005) for the procedures of SADCP data processing and analysis, the first bin in the upper $8.3 \mathrm{~m}$ depth was removed from the data because of high acoustic noise. In this study, one current profile measurement was averaged from 200 ensembles. Depending on local bathymetry, the number of depth bins varied between 2 and 6 (equal to a water column of 8 to $48 \mathrm{~m}$ ).

SADCP data acquisition was based on the VMDAS (Teledyne RD Instrument, 2005) data with a short time averaging (STA) recording mode at every 2 minutes. The procedure to obtain corrected current data was: (1) convert from VMDAS data format to the net CDF format; (2) validate the data by applying data quality indicators; (3) comparing the measured current with vessel speed; (4) adding bathymetry data along the transect; (5) generating tidal current prediction from TPX 07; (6) applying a barotropic tidal current correction, and (7) data filtering. In this study, bathymetry data was derived from GEBCO with horizontal resolution of 1 minute $(1.852 \mathrm{~km})$.

Tidal current predictions, based on altimetry measurements of TOPEX/Poseidon and Jason, was obtained from the global inverse solution TPX07 (Egbert and Erofeeva, 2002) with 10 tidal components (M2, $\mathrm{S} 2, \mathrm{~N} 2, \mathrm{~K} 2, \mathrm{~K} 1, \mathrm{O} 1, \mathrm{P} 1, \mathrm{Q} 1, \mathrm{Mf}$, and Mm). This tidal current prediction was used to correct the data and to obtain filtered current data (non-tidal current). Data filtering was applied by a $1 / 41 / 21 / 4$ linear filter of the ocean current as a function of depth and time. The along a track plots of two the dimension (2D) corrected ocean currents and vectors were averaged every $1 \mathrm{~km}$.

\section{RESULTS AND DISCUSSION}

\subsection{Quasi Synoptic Near Surface Tempe- rature and Water Circulation}

Seawater temperature at about $8 \mathrm{~m}$ depth, obtained from hull mounted SADCP temperature sensor, exhibits distinct spatial 
temperature variation (see Figure 2). In the northern survey area, warm water $\left(\mathrm{T}>31^{\circ} \mathrm{C}\right)$ is found, which may represent warm coastal waters. However, cold water $\left(<30^{\circ} \mathrm{C}\right)$ is found along the southern transect and around southeastern Matasiri waters. In a station closed to south of the Kalimantan peninsula, distinct warm water $\left(\sim 32^{\circ} \mathrm{C}\right)$ is found locally, while much cooler water $\left(\sim 29.5^{\circ} \mathrm{C}\right)$ is seen in the southeastern part of Matasiri. Relatively cold water may be derived from the offshore waters. These hydrographic properties are discussed in more detail in the next section (Section 2.b).

The vertically averaged total current vectors along the cruise-track between 21 and 27 November 2010 revealed strong currents in the shallow northeastern waters, around a eastern Matasiri waters, as well as along the southern transect (Figure 3a). Near the Kalimantan peninsula a convergence of currents was observed. This synoptic current vector represents total current components (both tidal and non-tidal current). Tidal current prediction in the study area, obtained from the global inverse solution TPXO of tidal prediction (Egbert and Erofeeva, 2002), the oscillates generally north-westward (southeastward) during the flood (ebb) time and dominated by diurnal component (not shown), which is in good agreement with model of Hatayama (1996) and Koropitan et al. (2006).

The non tidal current (Figure $3 b$ ) is relatively weak in the northwestern part of the study area, but strong northeastward current persists around the eastern Matasiri Islands with a magnitude exceeding $55 \mathrm{~cm} / \mathrm{s}$ (Figure
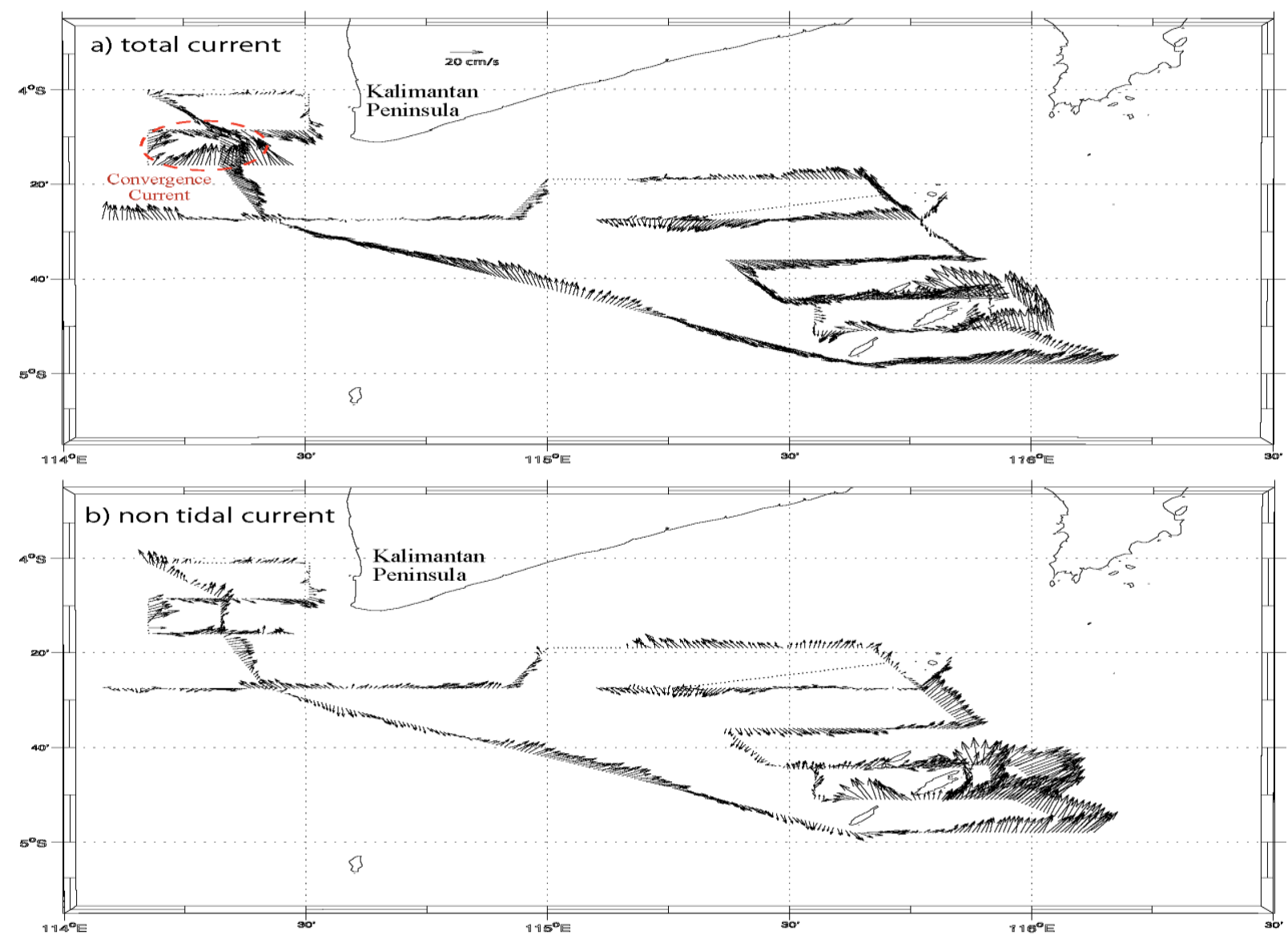

Figure 3. Vertically averaged velocity along the cruise-track, (a) total current and (b) non-tidal current (total current subtracted by tidal current). 
3b). This strong current may be part of the seasonal Java Sea Current that meanders near southern Kalimantan due to a topographic changes, which would be in good agreement with ship drift data (Wyrtki, 1961). Further discussion of monsoonal current bifurcation is presented in the last section (Section 3; see Figure12).

\subsection{Hydrographic Properties and Cur- rent Pattern along Sections: the $\mathrm{Ob}$ - served Coastal Front}

In this section the vertical structure of seawater properties and ocean currents along two transect lines (A-B and C-D lines) are presented, representing the southern and northern boundaries of the study area.

$A-B$ Line. Distinct warm $\left(>30^{\circ} \mathrm{C}\right)$, fresh $(<28 \mathrm{psu})$ and less dense $\left(<18 \sigma_{\theta}\right)$ water was found in the western part of the A-B line (Figure 4a-c). The thickness of this surface layer varied between $\sim 20 \mathrm{~m}$ in the stations closed to point depart $\mathrm{A}$ and $\sim 5 \mathrm{~m}$ in the stations distanced of about $175 \mathrm{~km}$ from point A. This surface layer represents coastal water, which may be supplied mainly from the Barito River discharge. Further east along the A-B transect was occupied by cool $\left(<30^{\circ} \mathrm{C}\right)$, saline $(>30 \mathrm{psu})$ and dense $\left(>19 \sigma_{\theta}\right)$ offshore water. Coastal water was associated with a higher stability frequency or BruntVaisala frequency, chlorophyll-a and dissolved oxygen (DO), in contrast to the offshore water (Figure 4d-f). A coastal thermohaline front of high horizontal gradient of temperature, salinity and density was located in the transition zone between coastal and offshore water near $150 \mathrm{~km}$ (Figure 4a-c).

The vertical structure of the zonal and meridional current components shows spatial variation of the current along the A-B line. Since the bathymetry in the study area is generally shallow, vertical variation of the current is relatively small. A much stronger eastward current was found east of $150 \mathrm{~km}$ (east of $114^{\circ} 45^{\prime} \mathrm{E}$ ) (Figure 5a), where the current vectors are dominated by eastward northeastward flow. Southeastward flow was observed near the Kalimantan peninsula $\left(114^{\circ} 30^{\prime} \mathrm{E}\right)$ and near Matasiri $\left(115^{\circ} 30^{\prime} \mathrm{E}\right)$. The latter was associated with the frontal zone found crossing this line (see Figure 4). The vertical structure of the averaged current profiles along the A-B line showed much stronger zonal than meridional current in the upper $20 \mathrm{~m}$ depth, although the meridional flow was stronger at depth (Figure 5b). Nevertheless, both components had positive values, meaning that mean current vector flows northeastward across the A-B line.

$\mathrm{C}-\mathrm{D}$ Line. In the upper $10 \mathrm{~m}$ depth, warm fresh and less dense water was predominant along the C-D line, implying no transition zone of coastal and offshore water. The warm fresh and less dense surface layer alternates, suggesting an intense mixing between the surface and deeper water (Figure 6 a-c). Deeper layers showed relatively homogenous water in temperature and salinity, except at the beginning and at the end of the transect where hydrographic properties were slightly changed. For example, cool fresh and less dense water of the deeper layer in the west occurred, in which was not observed in the east. The surface layer exhibited weak static stability (Figure 6d). Potentially, this may lead to mixing of water masses in the upper $10 \mathrm{~m}$ depth, particularly east of $150 \mathrm{~km}$ (east of $114^{\circ} 45^{\prime} \mathrm{E}$ ). Chlorophyll concentration exhibited large fluctuations as well (Figure 6e). However, dissolved oxygen was fairly consistent with the temperature and salinity distribution with a much higher oxygen concentration in the upper $10 \mathrm{~m}$ depth (Figure 6f).

Water depth along C-D line was much shallower than that along the A-B line. Therefore, the SADCP data acquired along this line are available mostly from the first two bins, centered at $10.8 \mathrm{~m}$ and $15.8 \mathrm{~m}$ depth, respectively. A westward current dominated the western and eastern part of transect, with the middle mainly flows eastward (Figure 7a). The meridional current was mostly northward and was much stronger at the beginning and at the end of 
a)

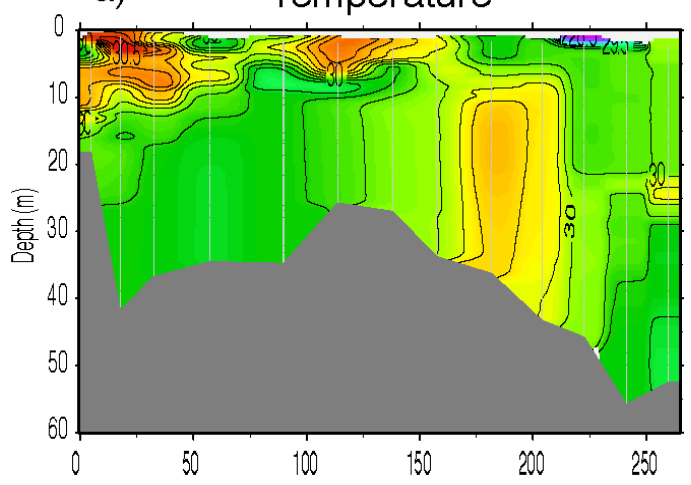

b)

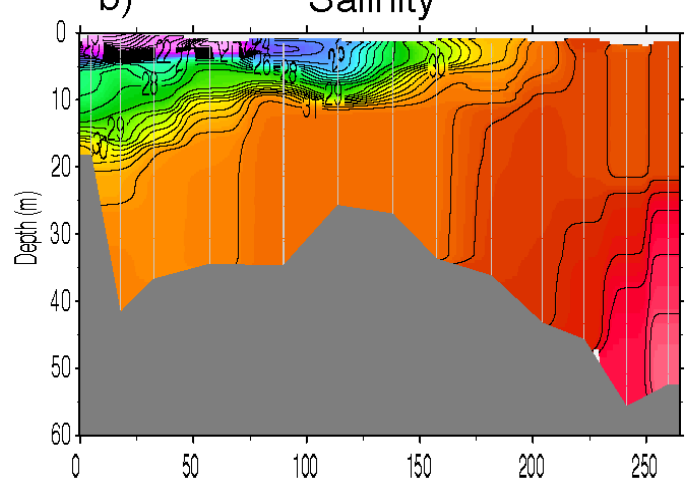

c)

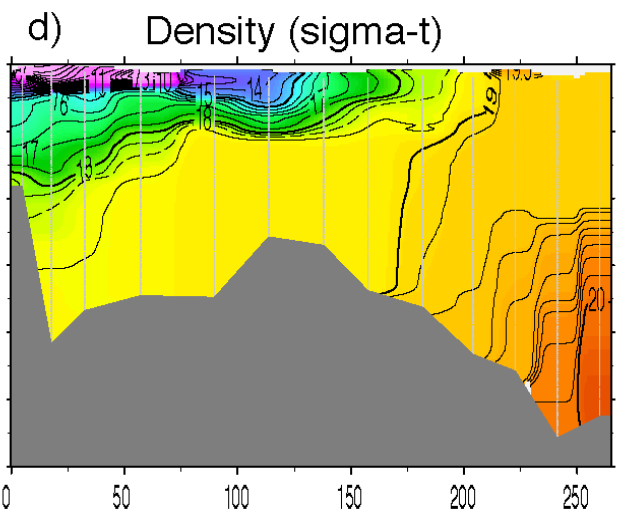

e)

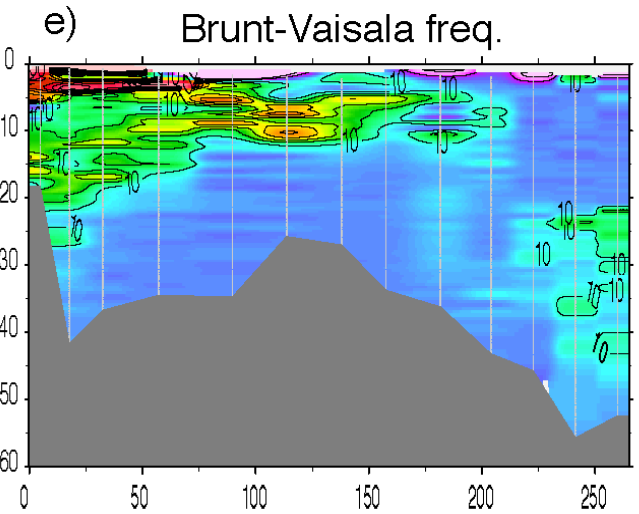

f) Dissolved Oxygen

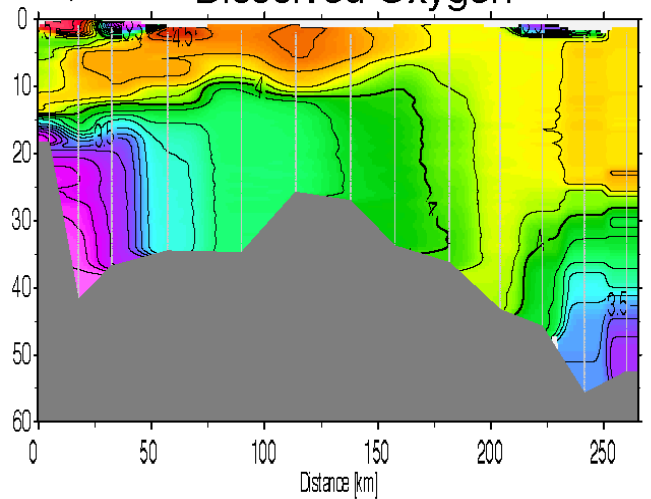

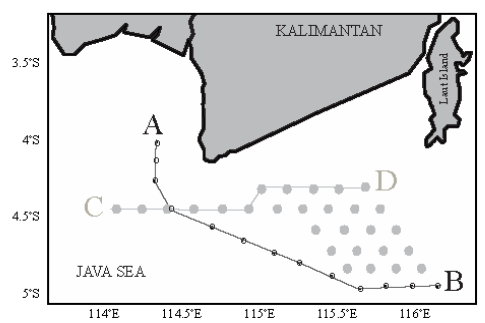

Figure 4. Vertical structure of seawater properties between A-B line (see inset); (a) potential temperature $\left({ }^{\circ} \mathrm{C}\right)$, (b) salinity (psu), (c) potential density anomaly $\left(\mathrm{kg} / \mathrm{m}^{3}\right),(\mathrm{d})$ Brunt-Vaisala frequency (cycle/hour), (e) chlorophyll- $a$ concentration $\left(\mathrm{mg} / \mathrm{m}^{3}\right)$, and (f) dissolved oxygen $(\mathrm{mg} / \mathrm{l})$. Color for each figure denotes the range value of parameters from low (violet) to high (red), overlayed with its contours. 

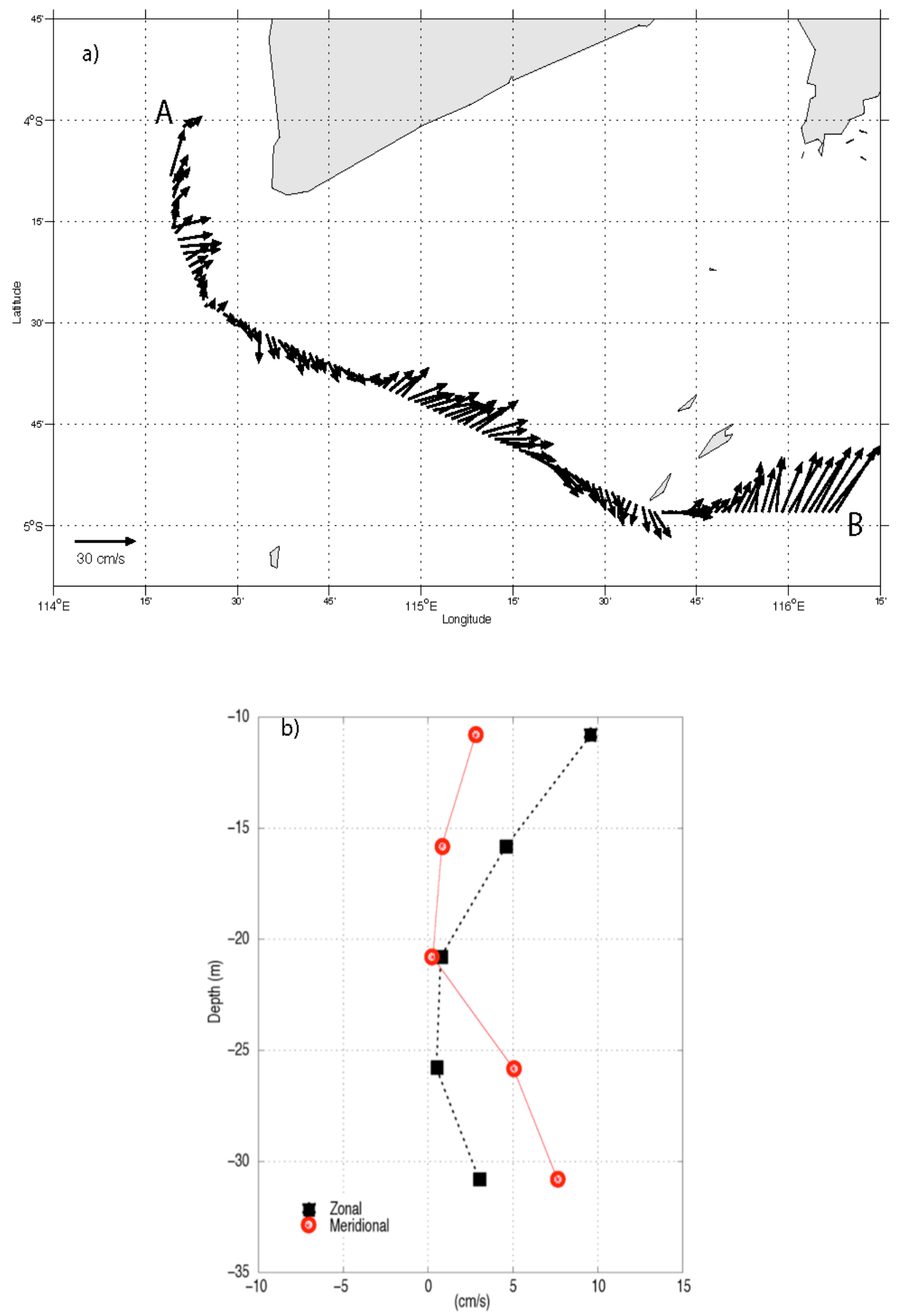

Figure 5. Vertical averaged current vector across the A-B line (a), and vertical structure of averaged zonal (black) and meridional (red) current components across the A-B line (b). 

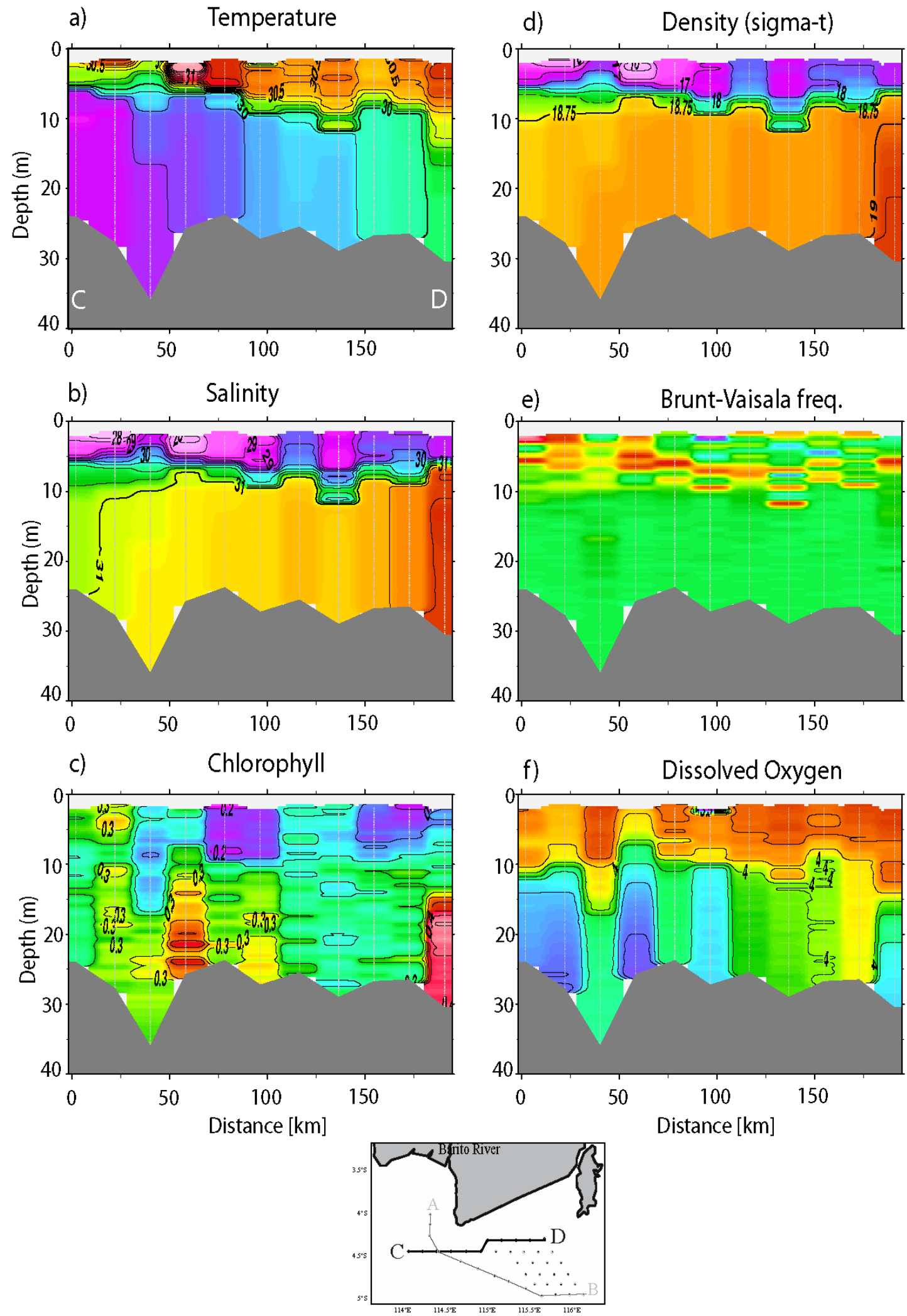

Figure 6. Same as Figure 4, but for the C-D line (see inset). 
the line. The spatial distribution of current vectors across the line varied between northeastward and westward flows (Figure 7a). The vertical structure of the averaged zonal current component across C-D line indicated a weak westward current at $10 \mathrm{~m}$ depth that increased slightly with depth (Figure 7b). The positive meridional current component was relatively constant at about $5 \mathrm{~cm} / \mathrm{s}$ throughout the water column (Figure 7b).
As described below, the coastal front can be identified in the A-B line, only, which was located near Matasiri Islands (see also Figure 4). To better understand the vertical structure and horizontal extent of the front, more details of the property distribution as well as of the circulation focused around the Matasiri Islands are presented in the following sections.
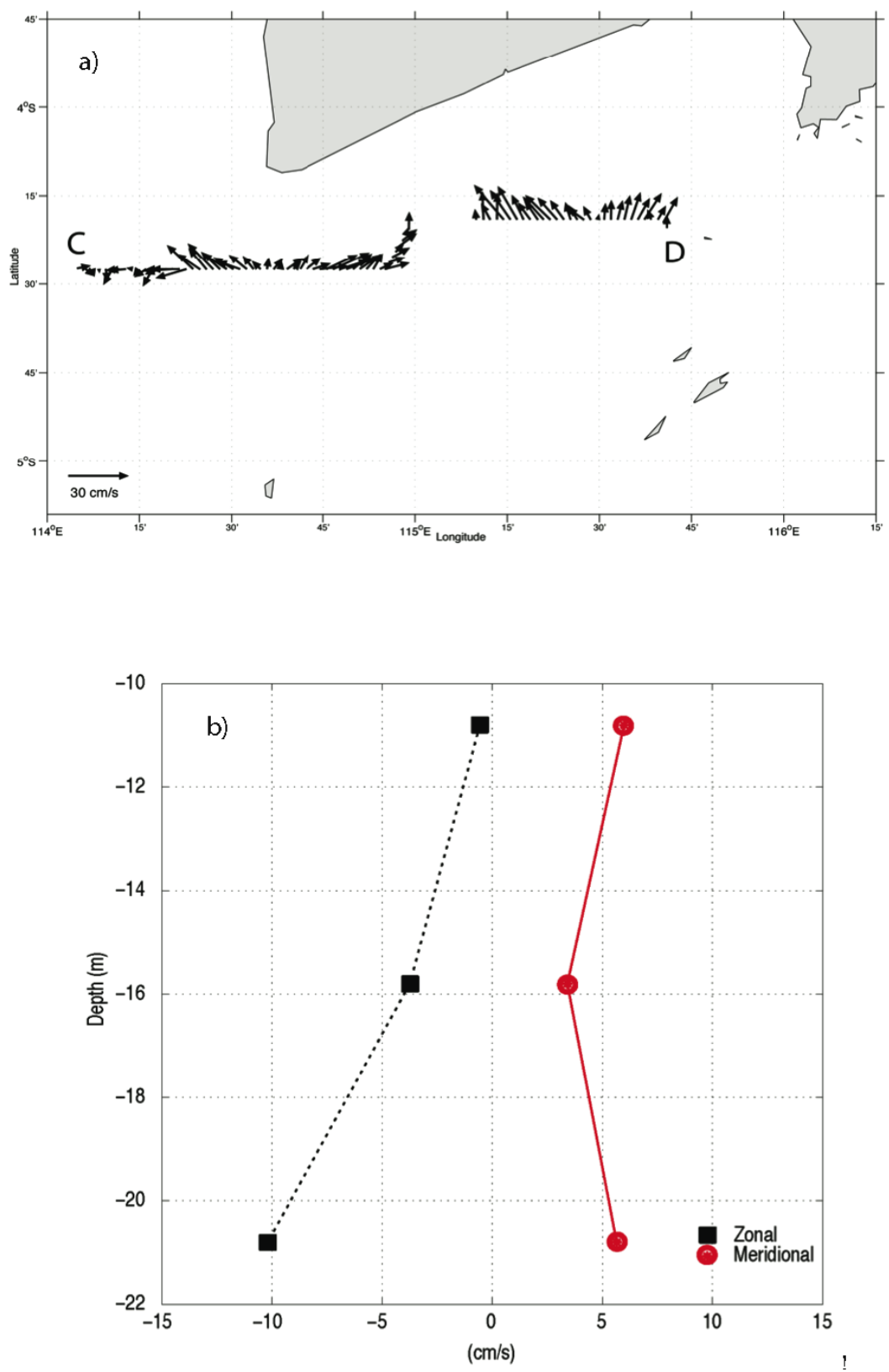

Figure 7. Same as Figure5, but for C-D line. 


\subsection{Structure of the Coastal Front and Circulation around the Matasiri Islands Waters}

The coastal front was clearly observed in Matasiri waters at $5 \mathrm{~m}$ depth level, stretching out from the southwest to the northeast and subsequently to the east. The center of the front, indicated by sharp horizontal gradients in salinity and density, is at the isohaline of $30 \mathrm{psu}$ and isopycnal of $18 \sigma_{\theta}$ (Figure 8b-c).
To the northwest from this zone, warm fresh and less dense coastal water was evident; while to the southeast cool saline and dense water was found. At $10 \mathrm{~m}$ depth, the front was still readily observed, particularly based on the salinity distribution. Thus, the density field was controlled mainly by salinity (Figure 8 b-c). However, the spatial distribution of the temperature at this front was associated with much warmer water. At $15 \mathrm{~m}$ depth, salty offshore water

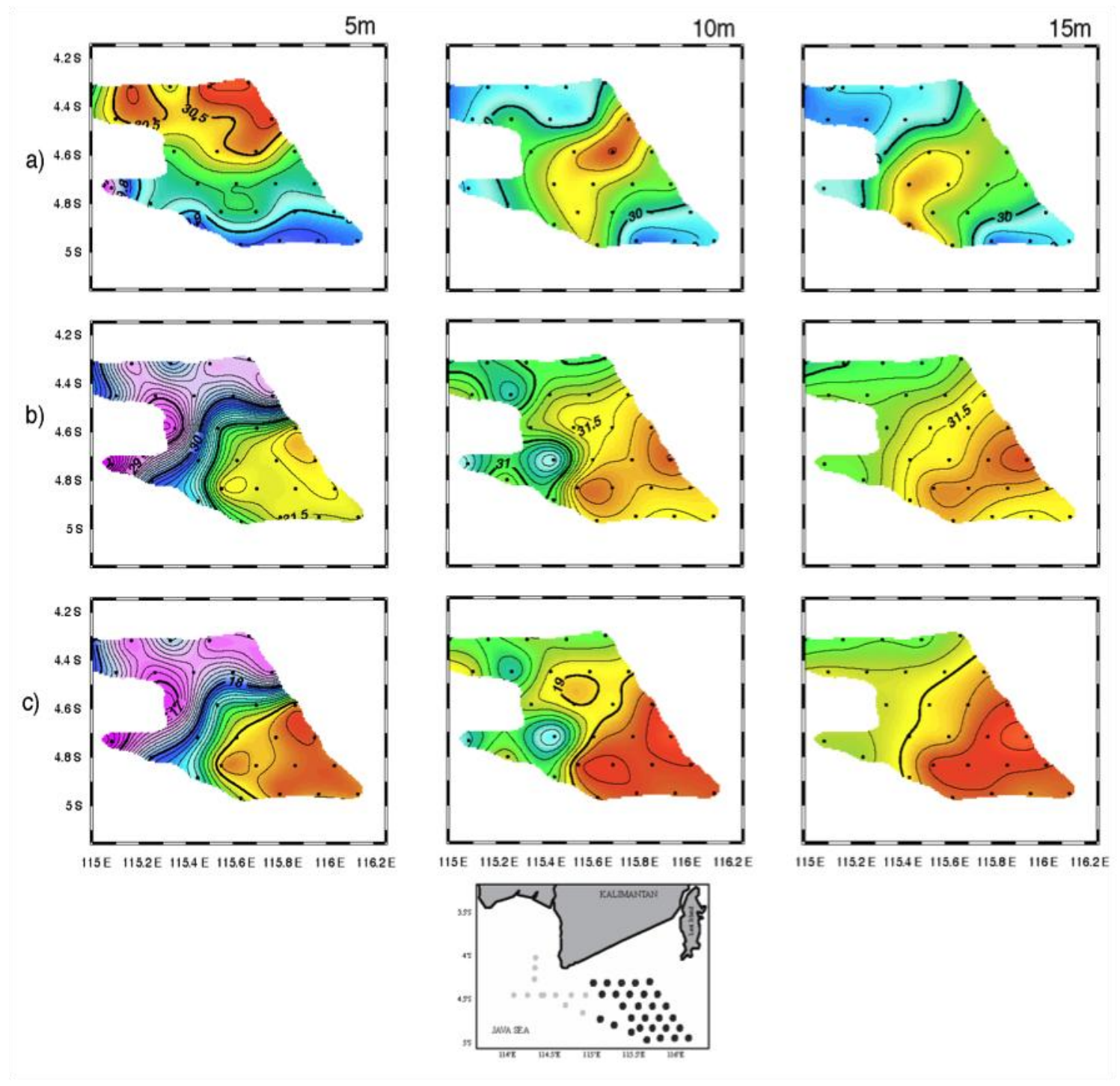

Figure 8. Horizontal distribution of seawater properties at $5 \mathrm{~m}, 10 \mathrm{~m}$ and $15 \mathrm{~m}$ depth in Matasiri waters: (a) potential temperature, (b) salinity, and (c) potential density. Color for each figure denotes the range value of potential density anomaly from low (violet) to high (red), overlayed by its contour of $0.1 \mathrm{~kg} / \mathrm{m}^{3}$ interval. Coastal front was seen obviously at $5 \mathrm{~m}$ depth. 
was dominant, shifting northward (Figure 8b).

It is interesting to note that the front during this survey was aligned to the northeast and then to the east, which may be related to the circulation pattern in the region. Here, we plotted the current vector (Figure 9a-b) at $8 \mathrm{~m}$ and $15 \mathrm{~m}$ depths overlaid with the density distribution. The strongest current appeared near the southeastern the Matasiri Islands flowed toward northwest and north east (Figure 9a).

These currents supply dense (>19 $\left.\sigma_{\theta}\right)$ offshore water into the region, where part of the water was advected farther northwest, controlling the frontal zone in the northwesttern islands. In the southwestern islands, the $19 \sigma_{\theta}$ isopycnal stretched out to the southeast, which fits within the eastward and than southeastward flows across the line. To the northwest of $19 \sigma_{\theta}$, the current pattern was generally weak and variable, flowing toward the south and the southeast. These currents bring less dense coastal water to the frontal zone. However, much stronger northeastward current occurred around $18 \sigma_{\theta}$ as is evident in the northern Matasiri, implying the front is aligned to the east.

At $15 \mathrm{~m}$ depth level, the flow pattern was similar to that in the upper level $(8 \mathrm{~m}$ depth), where the strongest currents persisted around the southeastern islands, and weak and than variable currents were found in the northwestern islands (Figure 9b). However, at this depth, the water mass was predominated by the deeper offshore water. Above 19 $\sigma_{\theta}$, the isopycnal was shifted farther northwest, but was still aligned in the southwestnortheast direction. At this depth, the front was not evident, suggesting that the less dense coastal layer is confined above this depth level.

Here, we examine profiles of temperature, salinity and density, and the temperature salinity relationship around Matasiri Islands (Figure 10a-d). We confirmed that the fresh water layer thickness deepened to about $10 \mathrm{~m}$ depth (Figure $10 \mathrm{a}-\mathrm{c}$ ). On the other hand, cool saline and dense offshore water was dominant from surface down to deeper layer (red). A contrast between coastal (blue) and offshore (red) water was evident at $20 \mathrm{~m}$ depth (Figure10 b-c). The transition zone of the two water masses was well defined at about $5 \mathrm{~m}$ depth, where the strongest horizontal gradient of properties appeared (see Figure 9a). Water masses in the front zone (green), as a result of horizontal mixing between the coastal and offshore waters, are evident in the salinity and density profiles. Finally, different characteristics of the warm fresh and the less dense coastal water mass (blue), the front water mass (green), and the cool saline and dense offshore water mass (red) was evident (Figure $10 \mathrm{~d}$ ). The offshore water places on surface density exceeding $19 \sigma_{\theta}$ with small variation of properties, while coastal water occupied below $19 \sigma_{\theta}$ and has a larger variation in salinity and temperature.

\subsection{Discussion}

The hydrographic observations the reported here revealed a warm fresh layer that stretches out to the south up to $5^{\circ} \mathrm{S}$ (about $167 \mathrm{~km}$ from the Barito River estuary to the south) and to the southeast just west of Matasiri Islands, associated with high chlorophyll $a$ and dissolved oxygen concentration. This fresh coastal water is probably derived mainly from the Barito River discharge. A direct measurement of the mean Barito River discharge volume near the estuary during a tidal period, carried out at the same time with a hydrographic survey, was measured by about $3,466 \mathrm{~m}^{3} / \mathrm{s}$ (Kusmanto et al., 2011). In fact, the Barito River estuary system consists of three rivers, where the biggest is Barito River with two other rivers just west of the Barito River outflow (see Figure 1). Thus, the total of three rivers discharge at that snapshot measurement are at least of the order of $7000 \mathrm{~m}^{3} / \mathrm{s}$. This large plume extension may have been modulated by the inter-annual climatic variability from the 2010 La Nina event, since the Climate Pre- 


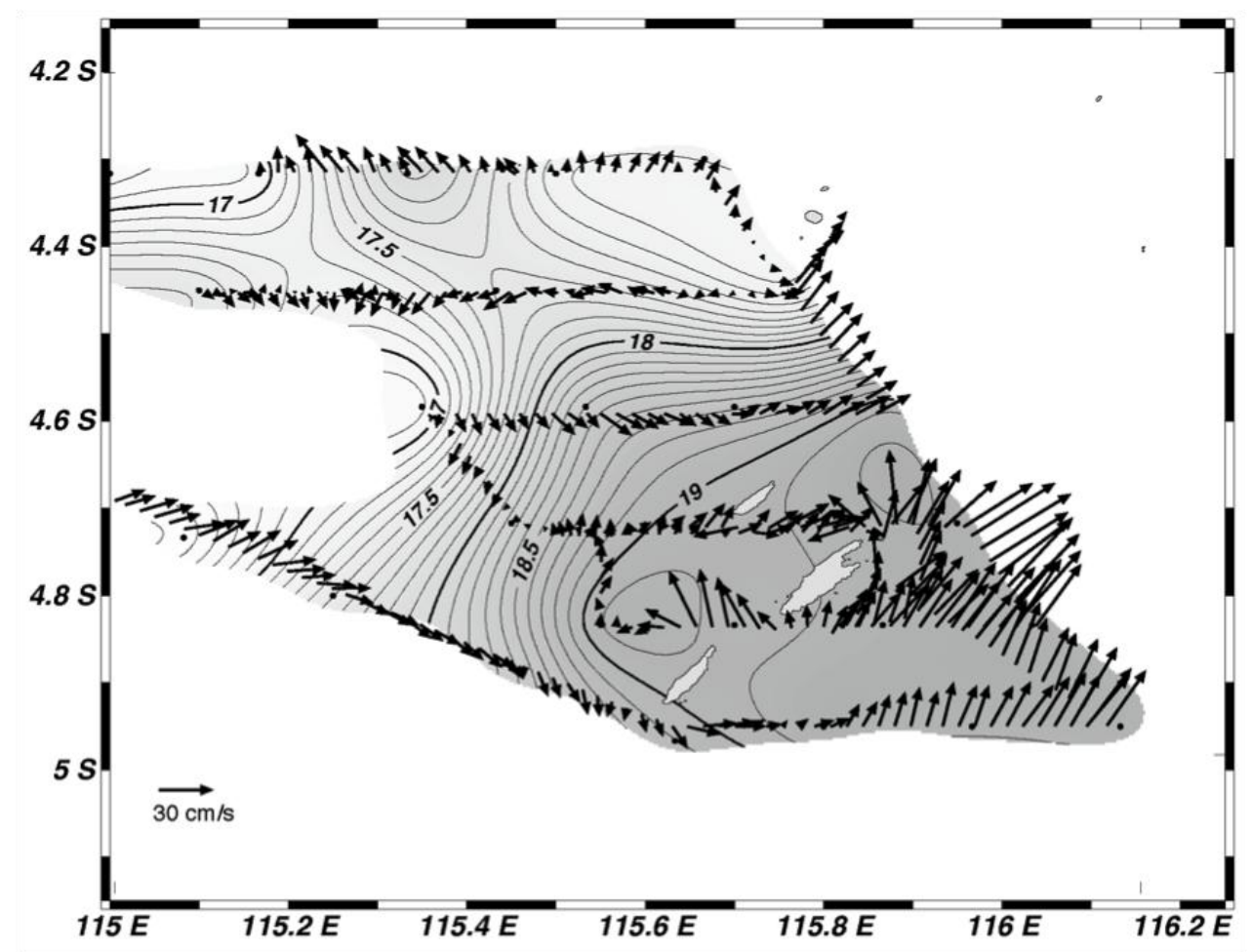

Figure 9a. Horizontal distribution of potential density on surface level $=5 \mathrm{~m}$, overlayed with current vector at $8 \mathrm{~m}$ depth. Front area is indicated by a strong density gradient at the central of study area (centered on isopycnal of 18). Contour interval for potential density is $0.1 \mathrm{~kg} / \mathrm{m} 3$.

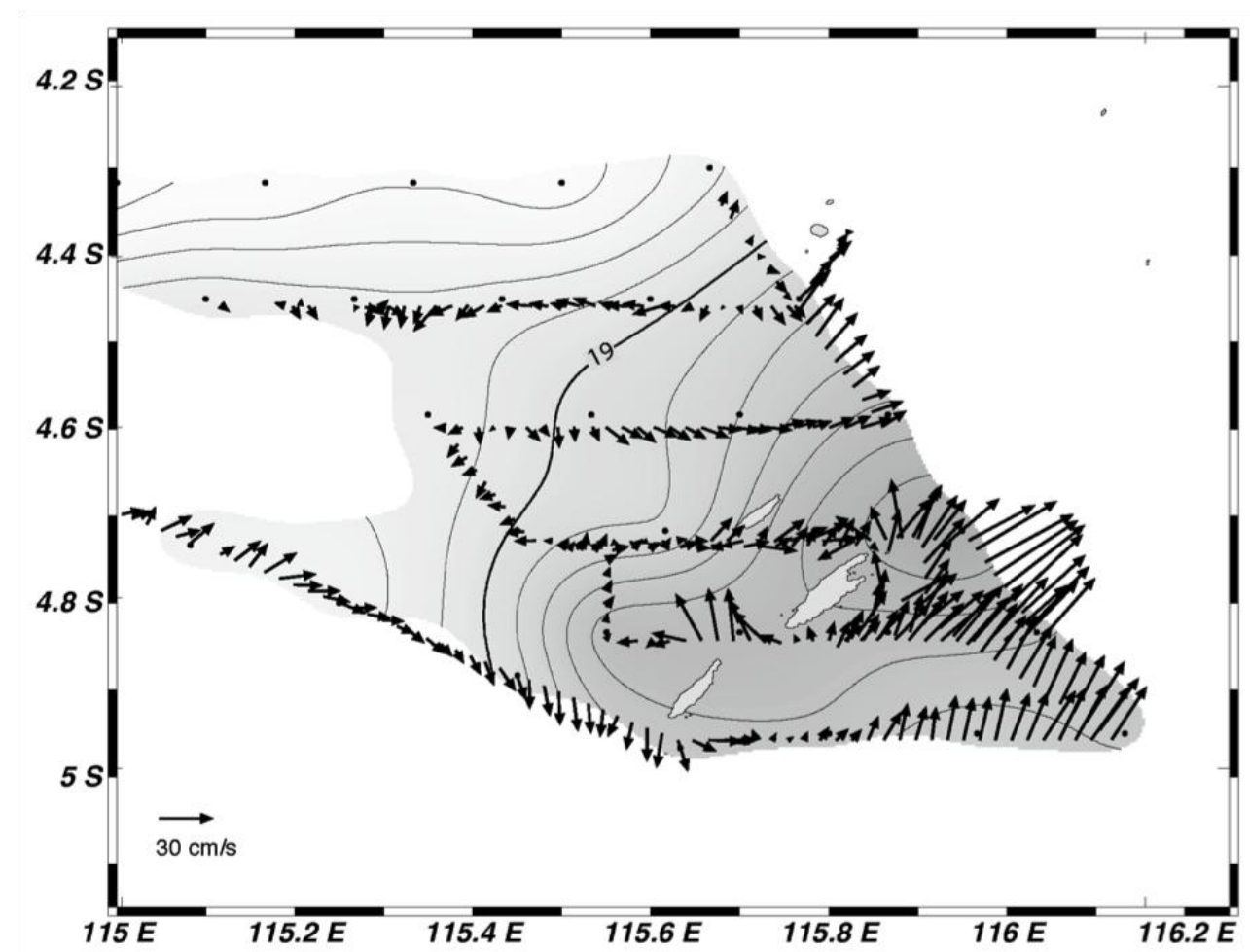

Figure 9b. Same as Figure 9a, but for density and current vector at $15 \mathrm{~m}$ depth level. 

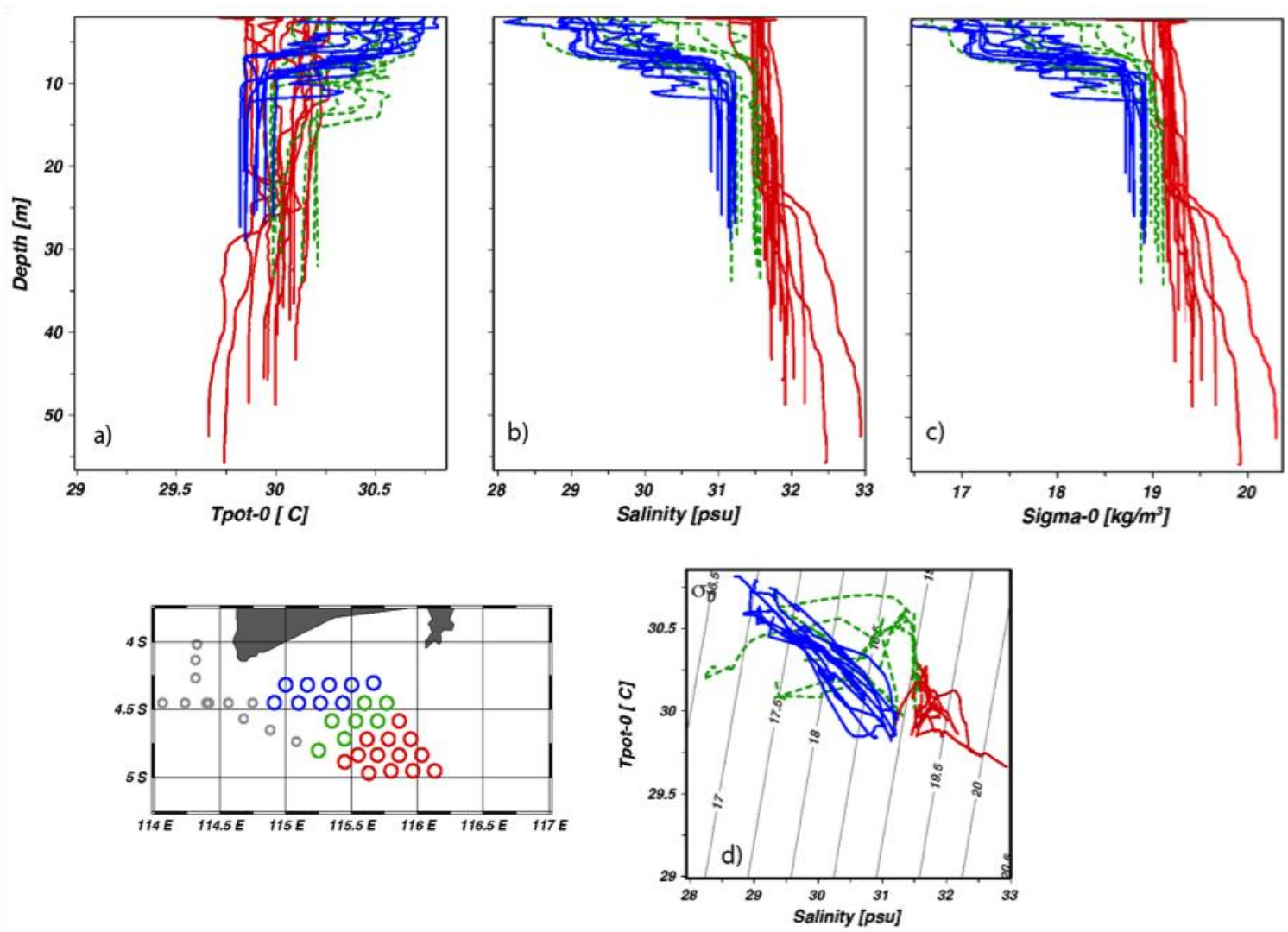

Figure 10. Vertical structure of (a) potential temperature, (b) salinity, (c) potential density, and (d) temperature-salinity diagram in Matasiri waters, coastal (blue), frontal (green) and offshore (red). The contrast between coastal and offshore seawater properties can clearly be seen, where transition between these properties represent the front water.

diction Center Merged Analysis of Precipitation (CMAP) precipitation data indicates anomalously high amounts of precipitation over the region in 2010 (Figure $11)$.

We observed that the thickness of the fresh water layer along the southern survey transect varies between $20 \mathrm{~m}$ at the NW survey area (closer to fresh water plume source) and $10 \mathrm{~m}$ near the frontal zone, suggesting intensive tidal mixing of the saltier layer beneath the fresh surface layer. Along this transect, the transition zone (frontal zone between fresh coastal water and salty offshore water was developed just southwest of the Matasiri Islands. Following Yanagi et al. (1995) and Yoshida and Oakey (1996), the Froude number $\left(\mathrm{F}_{\mathrm{ri}}\right)$ at the front can be determined, as follows:

$$
F_{r i}=\frac{V_{g}}{V_{t}}=\frac{\sqrt{\frac{\left(2 h-h_{1}\right)\left(h-h_{1}\right)}{h(h+1)}} \sqrt{g \frac{\Delta \rho}{\rho} h_{1}}}{V_{t}}
$$

where $\mathrm{V}_{\mathrm{g}}$ is the moving speed of fresh water to the well-mixed region as a gravity current; and $\mathrm{V}_{\mathrm{t}}$ is the speed of tidal current flowing in the opposite direction to $\mathrm{V}_{\mathrm{g}}$; $\mathrm{h}$ is the water depth; $h_{1}$ is the thickness of the fresh water layer; $g$ is the gravitational acceleration $\left(9.8 \mathrm{~m} / \mathrm{s}^{2}\right) ; \rho$ is the density of the well-mixed region; $\Delta \rho$ is the density difference between the fresh water layer and the well mixed-layer. From Figure 4c, at the center of the front: $h=35 \mathrm{~m} ; \mathrm{h}_{1}=10 \mathrm{~m}$; $\rho=1018.84 \mathrm{~kg} / \mathrm{m}^{3}$; and $\Delta \rho=0.74 \mathrm{~kg} / \mathrm{m}^{3}$, yields $\mathrm{V}_{\mathrm{g}}$ of $\sim 29.11 \mathrm{~cm} / \mathrm{s}$. The amplitude of the tidal current $\left(\mathrm{V}_{\mathrm{t}}\right)$ at the front location was estimated at the order of $40 \mathrm{~cm} / \mathrm{s}$. Thus, the Froude number was estimated to be $<1.0$ 


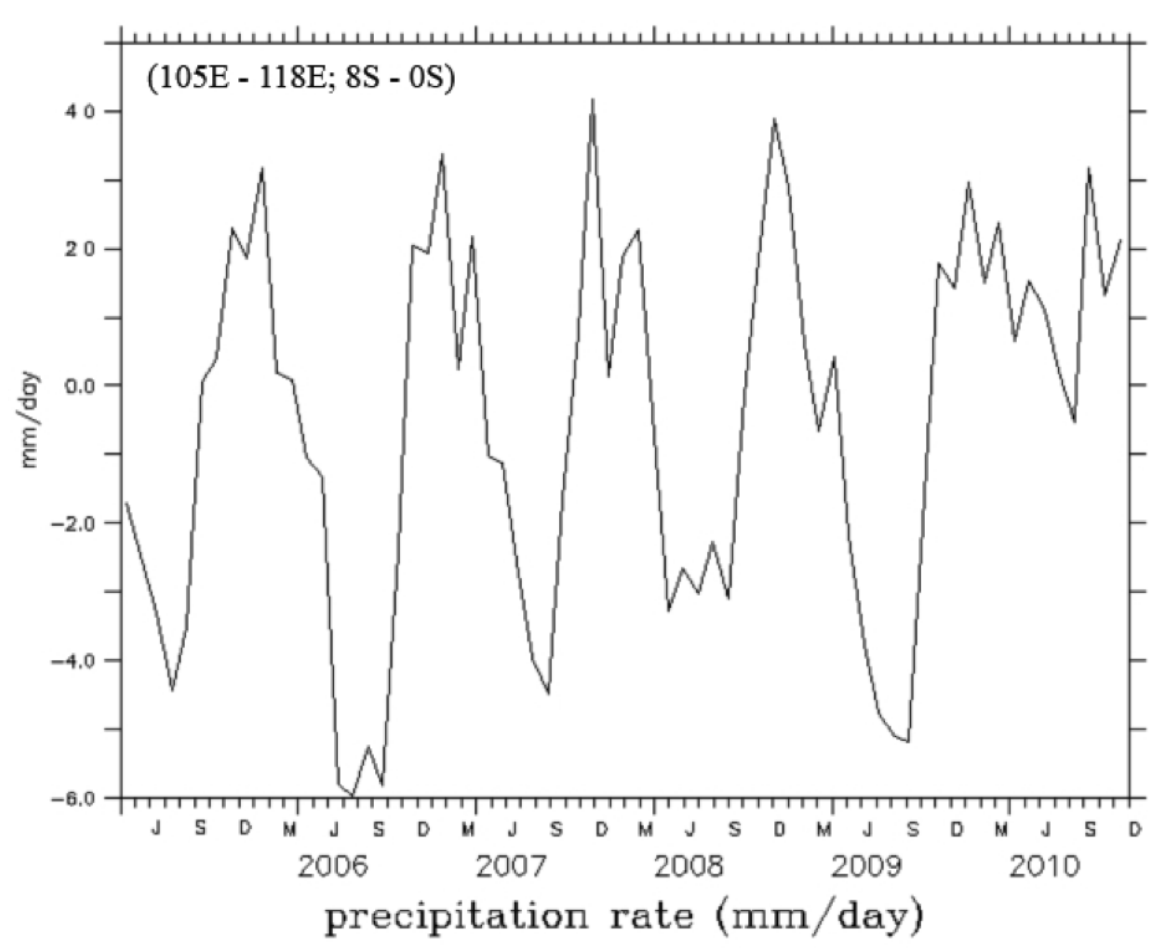

Figure 11. Time series of CMAP precipitation rate between 2005-1010, averaged over domain of (105E-118E; 8S-0S) in the Java Sea and adjacent area. Anomalously high precipitation occurred in 2010, related to La Nina climatic variability. (Source: CMAP precipitation data, provided by the NOAA/OAR/ESRL PSD, Boulder Colorado USA, http://www.esri.noaa.gov/psd).

(about 0.73), indicating that the observed front is not a tidal front where the moving fresh water layer is not eroded by tidal mixing at the front. At a typical tidal mixing front, the water column is well-mixed in shallow areas with stratification existing in deeper areas.

Finally, the modeling study of the circulation in the study area (INDESO, 2012) suggested a east-northeastward flow of the monsoon current during the Northwest Monsoon in the northern study area (Figure12). This monsoon current may bring the fresh water plume further eastward, since the observed fresh water layer is dominant along the northern transect (e.g., C-D line; Figure $6)$. On the other hand, the strong northeastward current near eastern Matasiri (see Figure 9) may represent a bifurcation of the monsoon current, as demonstrated by the model (Figure 12). This strong current constrains the extension of the fresh water plume, the shaping a transition zone (frontal area) that is aligned in the northeast east direction near western Matasiri.

The observed relatively saline water ( $\mathrm{S}>31$; Figure 8 ) on the offshore side represents fresh Java Sea water that is dominant during this 'rainy' Northwest Monsoon. We assume that during the 'dry' Southeast Monsoon, when salty Makassar water enters the Java Sea, two fronts develop near the study area. The first is a coastal front of a fresh water plume and offshore Java Sea water. The previous studies have been observed the front further southwest from the study area during different monsoon period, as the reported by Sadhatomo and Durand (1997). To fully understand the structure and dynamics of the coastal and offshore front developments in this important fishing ground area, a second continuous hydrographic survey during the SEM monsoon period is needed. 


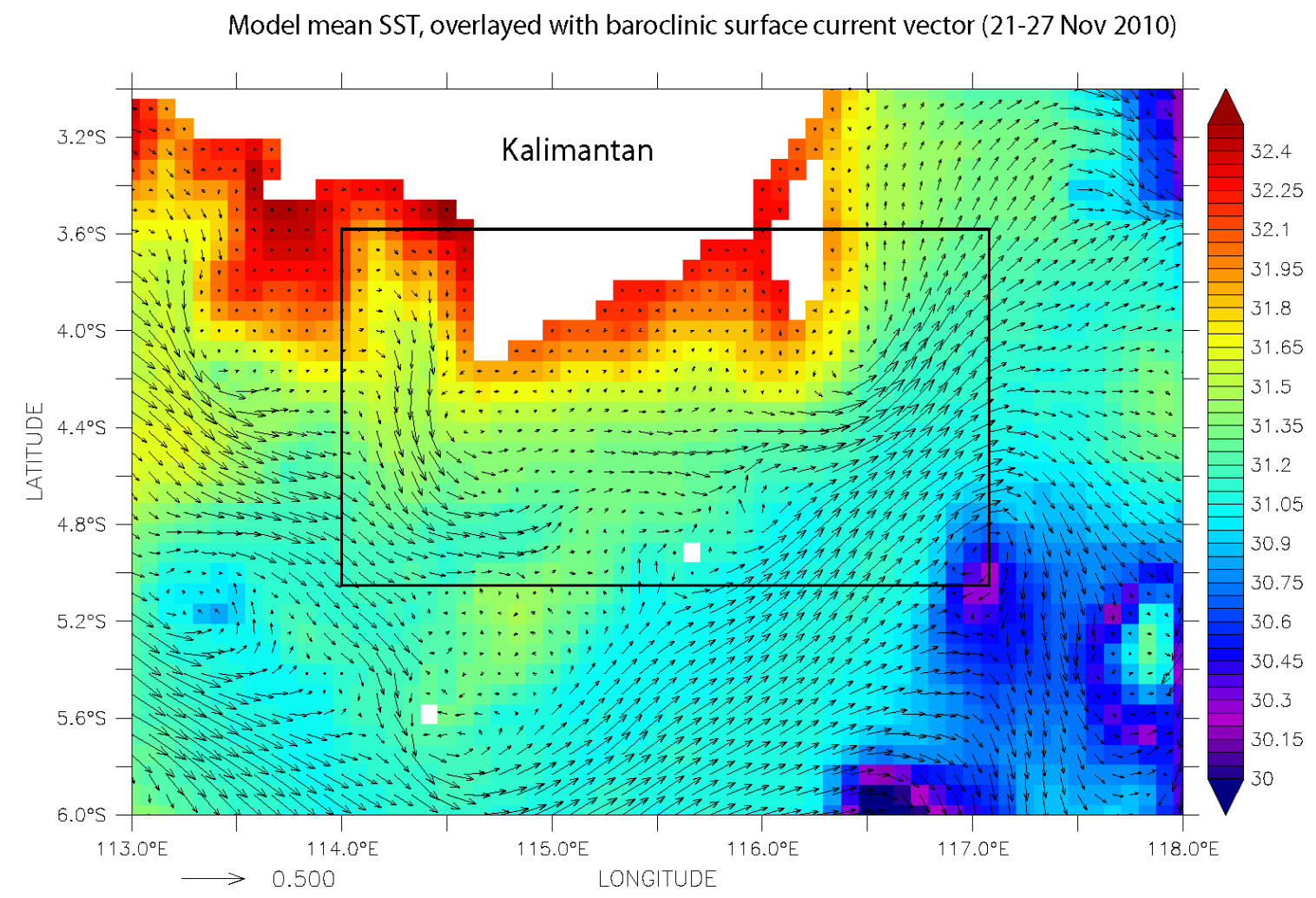

Figure 12. Model mean sea surface temperature, overlayed with the mean baroclinic surface current vector between 21 and 27 November 2010 around the study area. The hint-cast model result was obtained from the INDESO circulation modeling system (INDESO, 2012).

\section{CONCLUSION}

A coastal front was evident around western Matasiri Islands, separating a fresh coastal water plume from the Barito River discharge and the offshore Java Sea water. The thickness of the fresh water layer along the southern transect was about $20 \mathrm{~m}$ on the western side because of its proximity to fresh water source from Barito River and more shallow $(\sim 10 \mathrm{~m})$ to the southeast near the frontal zone.

A weak mean eastward current in the northwestern Matasiri Island brought fresh coastal water further eastward. However, a strong northeastward flow carrying salty offshore water forced the fresh coastal water to be aligned in the northeast and east direction around Matasiri island. Therefore, the transition zone (front) of fresh coastal and salty offshore waters formed a similar pattern.

\section{ACKNOWLEDGEMENTS}

This study was supported by Ministry of Education and Culture National Indonesia. The authors would like to thank Prof. Djoko Santoso of DIKTI and Prof. Herry Hardjono of LIPI for their keen interests to develop such a joint-research program. We are indebted to Captain Daniel, and the crew and Engineers of BJ8, particularly Priyadi D.S. and Muhadjirin for their professional services during the cruise. We also express our gratitude to our colleagues (M. Hasanudin and Wahyu) and onboard participants for fruitful discussions. We thank Dr. Janet Sprintall of Scripps Institution of Oceanography US for valuable comments and suggestions to improve the early manuscript. 


\section{REFERENCES}

Atmadipoera, A. 2009. Indonesian throughflow water at the major outflow straits: from INSTANT observation and numerical model. Thesis. Graduate School of Environment of Ilede-France, the University of Pierre et Marie Curie (Paris 6). 215p.

Atmadipoera, A., R. Molcard, G. Madec, S. Wijffels, J. Sprintall, I. Jaya, and A. Supangat. 2009. Characteristics and variability of the Indonesian throughflow water at the outflow straits. Deep Sea Research I, 56:1942-1954.

Egbert, G.D. and S. Erofeeva, 2002. Efficient inverse modeling of barotropic ocean tides. J. Atmos. and Oceanic Tech., 19:183-204.

Hatayama, T., T. Awaji, and K. Akimoto. 1996. Tidal currents in the Indonesian Seas and their effect on transport and mixing. J. of Geophys. Res., 101 (C5):12,353-12,373.

Hendiarti, N. Suwarso, E. Aldrian, K. Amri, R. Andiastuti, S.I. Sachoemar, and I.B. Wahyono. 2005. Seasonal variation of pelagic fish catch around Java. Oceanogr., 18(4):112-123.

Infrastructure Development of Space Oceanography (INDESO) Project. 2013. The physical ocean. http://www. indeso.web.id/indeso_wp/index.php /forecasts/. [Accessed on 12 May 2014].

Koropitan, A.F. and M. Ikeda. 2008. Threedimensional modeling of tidal cir culation and mixing over the Java Sea. J. of Oceanogr., 64:61-80.

Kusmanto, E., M. Hasanudin, D.P. Santoso, and Muhadjirin. 2011. Direct estimate of the Barito River discharge during a tidal period. Cruise Report of the joint research DIKTI-LIPI of Matasiri cruise November 2010. 25p.

Munasik and R.M. Siringoringo, 2011. Struktur komunitas karang keras (Scleractinia) di perairan pulau Maraba- tuan dan pulau Matasiri, Kalimantan Selatan. J. Ilmu Kelautan, 16(1):4958.

Pasaribu, B.P., D. Manurung, and D. Nugroho. 2004. Fish stock assessment using marine acoustics detection and oceanographic characteristics in Java Sea. Gayana, 68(2):466-475.

Petit, D., P. Cotel, and D. Nugroho. 1996. The seasonal variations of salinity in the Java Sea. Proceeding of acoustics, Seminar akustikan 2. Bandung. 14p.

Potier, M. and T. Boely. 1990. Effect of environmental factors on the purse seine fishery of the Java Sea. Aquat. Living Resour., 3:193-205.

Purwangka, F., Fahmi, and A. Purwandana. 2012. Inventarisasi fauna ikan menggunakan bottom trawl di perairan kepulauan Matasiri, Kalimantan Selatan. Buletin PSP, 20(1):103-118.

RD Instrument. 2005. VMDAS acoustic doppler current profilers $75 \mathrm{kHz}$ users manual. Teledyne Technologies Incorporated, 14020 Stowe Drive, Poway, CA 92064. 60p.

Sadhotomo, B. and J.R. Durand. 1997. The Java Sea environment. In: Potier M. and S. Nurhakim. (eds.) BIODYNEX: biology, dynamics, exploitation of the small pelagic fishes in the Java Sea. AARD/ORSTOM. 14-38pp.

SeaSoft V2. 2006. SBE data processing, CTD data processing and plotting software (user's manual). Sea-Bird Electronics, Inc. $13431 \mathrm{NE} 20^{\text {th }}$ Street Bellevue, Washington 98005 USA. $174 \mathrm{p}$.

Schlitzer, R. 2009. User Guide for Ocean Data View (Multi-Platform Version 4.4). Alfred Wegener Institute for Polar and Marine Research, Bremerhaven, Germany. 62pp. [Available online at http://odv.awi.de/en/documentation/].

Thoha, H. and K. Amri. 2011. Komposisi dan kelimpahan fitoplankton di perairan Kalimantan Selatan. J. Oseano. 
dan Limno. di Indonesia, 37(2):371382.

Tozuka, T., T. Qu, and T. Yamagata. 2007. Dramatic impact of the South China Sea on the Indonesian Throughflow. Geophys. Res. Letter, 34:L12612.

Wijaya, N.I. and R. Pratiwi. 2011. Distribusi spasial krustasea di perairan kepulauan Matasiri, Kalimantan Selatan. $J$. Ilmu Kelautan, 16(3):125-134.

Wyrtki, K. 1961. Physical oceanography of the Southeast Asian Waters. Naga Report 2. Scripps Institution of Oce- anography, the University of California, La Jolla. 145p.

Yanagi, T., S. Igawa, and O. Matsuda. 1995. Tidal front at Osaka Bay, Japan, in winter. Cont. Shelf Res., 15(14)17231735.

Yoshida, J. and N. Oakey. 1996. Characterization of vertical mixing at a tidalfront on George Bank. Deep Sea Research Part II, 43(7-8):1713-1744.
Accepted :25 April 2015
Reviewed :26 May 2015
Approved : : 17 June 2015 